\title{
Energy balance in rats given chronic hormone treatment
}

\section{Effects of corticosterone}

\author{
By CHRISTOPHER J.H. WOODWARD* AND PETER W. EMERY \\ Nutrition Division, Department of Food and Nutritional Sciences, King's College $(K Q C)$, \\ Campden Hill Road, London W8 $7 \mathrm{AH}$
}

(Received 3 June 1988 - Accepted 20 December 1988)

1. Sprague-Dawley rats were given corticosterone for 4 to $14 \mathrm{~d}$ either by subcutaneous injection $(50 \mathrm{mg} / \mathrm{kg}$ body-weight per $\mathrm{d}$ ) or as a higher dose in the diet $(1 \mathrm{~g} / \mathrm{kg}$ dict). Energy balance was calculated using the comparative carcass technique.

2. Corticosterone significantly suppressed growth rate by at least $50 \%(P<0.001$ in all experiments). The reduction in growth was more marked in males than in females.

3. Hormone treatment significantly reduced metabolizable intake $(\mathrm{kJ} / \mathrm{d})$ in males but not in females. Expressed relative to either metabolic body size ( $\mathrm{kg}$ body-weight ${ }^{3 \cdot 75}$ ) or fat-frec mass, metabolizable intake tended to be increased in the treated groups.

4. Energy expenditure, calculated as the difference between metabolizable intake and gain and expressed as $\mathrm{kJ} / \mathrm{d}$, did not differ between treated and control rats. Relative to either metabolic body size or fat-free mass, expenditure was consistently increased in treated rats. This change was statistically significant in five of the cight comparisons.

5. The corticosterone-treated rat is characterized by high energy intake and expenditure relative to its body size and growth rate. Alterations in the relative sizes of different lean tissues may contribute to these changes

High doses of corticosteroids generally produce weight loss in animals. This is attributable to reduced lean body mass, with relatively little change in body fat (Kochakian \& Robertson, 1951; Hausberger \& Hausberger, 1958; Kekwick \& Pawan, 1965). Less is known about the effects of corticosteroids on energy balance. Despite substantial weight loss, cortisol-treated rats show no marked reduction of food consumption (Bellamy, 1964). Such evidence might indicate increased energy expenditure, but in rats treated with corticosterone this has not been consistently found (Coyer et al. 1985). Other studies in mice suggest that energy expenditure is reduced by corticosteroids (Babikian, 1962; Kekwick \& Pawan, 1965; Galpin et al. 1983).

In the present experiments we have, therefore, measured energy balance in corticosteronetreated rats using the comparative carcass technique. A preliminary account of the present work has already been published (Woodward \& Emery, 1986).

\section{MATERIALS AND METHODS}

\section{Animals}

Sprague-Dawley rats weighing approximately $140 \mathrm{~g}$ were obtained from the College animal colony and housed singly in plastic cages with wire-mesh bases. Groups of six rats were used. The animal house was maintained at $20-25^{\circ}$ with a $12 \mathrm{~h}$ light $-12 \mathrm{~h}$ dark cycle. The rats were given, ad. lib., water and a powdered semi-synthetic diet containing $210 \mathrm{~g}$ casein $/ \mathrm{kg}$ and with a gross energy content of $18.5 \mathrm{~kJ} / \mathrm{g}$ (Woodward \& Emery, 1989). The food pots were covered by metal grids to minimize spillage. Body-weight and the amount of food removed from the pots were measured every $2-4 \mathrm{~d}$.

Corticosterone (Sigma Chemical Co., Poole, Dorset) was suspended in a vehicle

* Present address: Department of Physiology, University of Leeds, Leeds LS2 9NQ. 
containing $(\mathrm{g} / \mathrm{l})$ : sodium chloride 8 , Tween 80 (polyoxyethylenesorbitan monooleate) 4 , sodium carboxymethylcellulose 5, benzyl alcohol 9 (Tomas et al. 1979). The hormone was injected subcutaneously once daily at $15.00-17.00$ hours using a dose of $50 \mathrm{mg} / \mathrm{kg}$ bodyweight. Control animals were injected with vehicle alone. In experiments using dietary corticosterone, the hormone was suspended in maize oil before mixing in bulk with the diet at a level of $1 \mathrm{~g} / \mathrm{kg}$ diet. On a body-weight basis, this dose was approximately double that injected. A higher dose was used in case low absorption or inactivation by the liver reduced the effectiveness of the oral route.

Experiments were initially planned to last for $12-13 \mathrm{~d}$. However, since males lost weight rapidly when treated with corticosterone, studies using this sex were terminated when the treated group weighed $30 \%$ less than the controls. The following experiments were carried out.

Expt 1: male rats were injected with corticosterone for $11 \mathrm{~d}$.

Expt 2: female rats were injected with corticosterone for $12 \mathrm{~d}$.

Expt 3: male rats were fed on corticosterone for $6 \mathrm{~d}$.

Expt 4: female rats were fed on corticosterone for $13 \mathrm{~d}$.

\section{Carcass analysis}

Carcasses were analysed using oven-drying and Soxhlet extraction as previously described (Woodward \& Emery, 1989). Random samples taken for nitrogen analysis using the Kjeldahl technique showed that $\mathrm{N}$ constituted a constant fraction of defatted dry matter (DDM) which was unaffected by corticosterone treatment, sex or age of rat. Carcass crude protein content was therefore routinely calculated as weight of DDM $\times 0.81$.

\section{Calculation of carcass gains and energy balance}

Initial composition was estimated using carcass analyses of basal groups of appropriate sex and weight (Woodward \& Emery, 1989). Gains of carcass components were then calculated by difference. Metabolizable energy intake was determined as the difference between dietary energy removed from the food pots and the pooled energy content of excreta and spillage. Urine, faeces and small amounts of spilled diet were collected together on plastic trays placed underneath the cages. After diluting and mixing in a blender, portions were freeze-dried and analysed by ballistic-bomb calorimetry.

Carcass energy content was calculated using energy densities of 39 and $19 \mathrm{~kJ} / \mathrm{g}$ for fat and DDM respectively. These factors were found from ballistic-bomb calorimetry of pooled samples. Energy expenditure, calculated by subtracting carcass energy gain from metabolizable intake, was expressed (1) per whole rat, (2) relative to metabolic body size $\left(\mathrm{kg}\right.$ body-weight ${ }^{0 \cdot 75}$ ), or (3) relative to fat-free mass.

\section{Statistical analyses}

Results are expressed as means with their standard errors. Means were compared using Student's unpaired $t$ test. Where the Fisher test indicated that variances were unequal, Cochran's approximation was used (Snedecor \& Cochran, 1978).

\section{RESULTS}

\section{Growth rate}

Since the designs of Expts $1-4$ were similar, the results are presented together. There were no deaths during the experiments, but polyuria was noted in the treated male rats in Expts 1 and 3 .

Weight gain in the treated males in Expt 1 was $1.9 \mathrm{~g} / \mathrm{d}, 76 \%$ less than that of the control group (Table 1). The treated females in Expt 2 gained $2 \cdot 3 \mathrm{~g} / \mathrm{d}$, half the rate of their controls. 
Corticosterone and energy balance

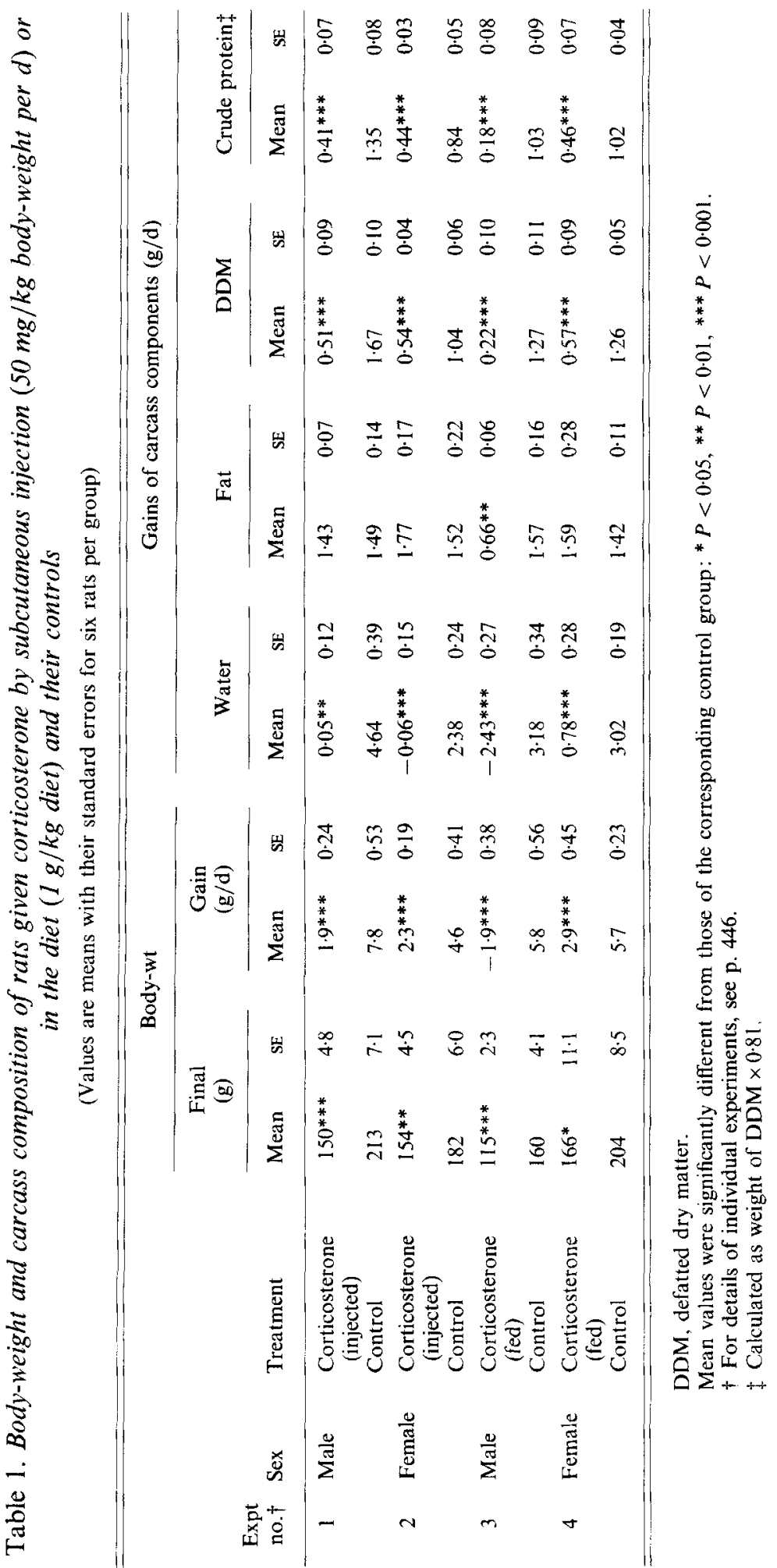


Thus, the females showed a somewhat smaller response to injected corticosterone than the males. A similar sex difference was found with dietary corticosterone: the male rats given corticosterone in Expt 3 actually showed a net weight loss, whereas the treated females in Expt 4 again grew at about half the rate of their respective controls.

\section{Carcass composition}

Gains of carcass water, fat and DDM are given in Table 1. The male rats injected with corticosterone (Expt 1) showed significantly lower gains of carcass water and DDM compared with their respective controls; the reduction in water was rather greater than that of DDM, both on an absolute and percentage basis. By contrast the accretion of fat was almost identical in the two groups. Corticosterone again caused significant reductions in water and DDM gain in Expt 2, and did not alter fat deposition.

In Expt 3, where growth suppression was most pronounced, a significant reduction in fat gain $(-58 \%)$ was found in addition to the losses in water and DDM. There was a net loss of carcass water and, as in Expts 1 and 2, this component accounted for most of the loss in body-weight. In Expt 4 with females, carcass fat was not reduced in the treated group and the lower gains of water and DDM followed a similar pattern to Expts 1 and 2 .

\section{Metabolizable intake}

In Expt 1, the metabolizable intake of the treated males was $303 \mathrm{~kJ} / \mathrm{d}, 12 \%$ lower than that of the control animals (Table 2). There was no effect of corticosterone on this variable in Expt 2. A comparable sex difference was found with dietary corticosterone: in Expt 3 the treated male rats had an intake $17 \%$ less than that of their controls, but there was no difference between the groups in Expt 4. When metabolizable intake was expressed relative to metabolic body size, the treated females in Expt 2 showed an increased intake, but no significant differences were observed in the remaining three experiments. When expressed relative to fat-free mass, metabolizable intake was significantly increased in the treated groups in Expts 1 and 2.

\section{Carcass energy gain}

Corticosterone significantly attenuated the rate of carcass energy gain $(\mathrm{kJ} / \mathrm{d})$ in the two experiments with males, by 27 and $66 \%$ for injected and dietary hormone respectively. In contrast this variable was not altered in either of the experiments with females.

\section{Energy expenditure}

When expressed per rat $(\mathrm{kJ} / \mathrm{d})$, there was no significant difference of energy expenditure in any of the four experiments, and in all cases the value for the treated group was within $6 \%$ of that for the controls. Relative to metabolic body size, expenditure was consistently higher in the treated groups by $4-16 \%$, but this difference was significant only in Expt 3 . In Expts 1 and 2, the difference was of borderline significance $(P<0 \cdot 1)$. Relative to fat-free mass, energy expenditure was consistently increased in the treated groups, by $11-17 \%$. This difference reached statistical significance in all cases.

\section{DISCUSSION}

When comparing animals of different size or composition, energy expenditure is usually expressed relative to either metabolic body size or lean body mass (Ford, 1984; Van Es, 1986). In the present study, fat-free mass has been used as an alternative to lean body mass (fat-free mass includes the non-lipid components of adipose tissue but excludes the lipids present in other tissues). Increased expenditure in the present case was most pronounced 
Corticosterone and energy balance

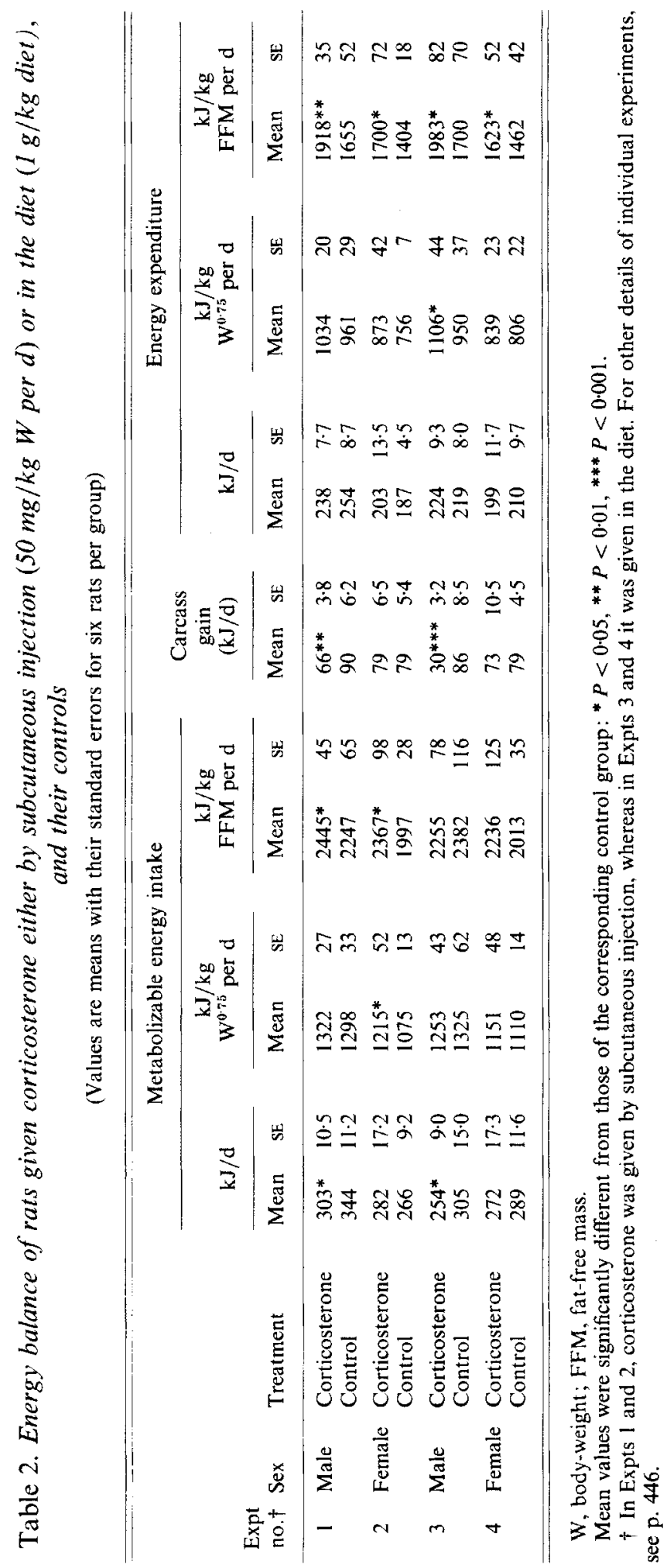


when expressed on the basis of fat-free mass, although increases were also observed relative to metabolic body size. However, the design of the experiments was such that, in addition to body size, the treated and control groups differed in growth rate and in metabolizable energy intake.

When growth is impaired, a reduction in energy expenditure is expected because of the lower costs of tissue deposition. In addition a reduction in body size is generally considered to result in lower expenditure per whole rat, because of reduced maintenance requirements. Such effects can be quantified using factorial methods (Pullar \& Webster, 1977; Webster, 1986). In the present experiments, none of the treated groups showed a reduced energy expenditure, despite differences in size and growth rate. Indeed some of the expressions showed increased expenditure in the treated groups, which is the converse of the effect predicted. Factorial methods suggest that such an increase might be attributable either to raised maintenance requirements or to a low efficiency of growth. The present results do not allow the contribution of these two processes to be distinguished. However, the known effects of corticosteroids, for example on protein turnover (Odedra et al. 1983) and on relative organ sizes (Fain \& Czech, 1975), suggest that both maintenance and growth costs might be affected. Such metabolic changes are discussed later.

Metabolizable energy intake per rat $(\mathrm{kJ} / \mathrm{d})$ was reduced by corticosterone in males, but not in females. The presence of glycosuria in the males suggests that urinary glucose loss may have contributed to this sex difference. Metabolizable energy intake relative to metabolic body size or fat-free mass tended to be increased in the treated groups. The magnitudes of the differences were in some cases as great as those found for expenditure. It might be argued that the increased expenditures were dependent on these high intakes. This would imply that corticosterone was inducing a form of dietary-induced thermogenesis. However, there is no evidence to support such a view; indeed, it is thought that corticosteroids suppress dietary-induced thermogenesis (Rothwell \& Stock, 1984).

Several biochemical mechanisms might contribute to the effects of corticosterone on energy expenditure. The possible role of increased amino acid oxidation has been discussed by Coyer et al. (1985). Corticosteroids also alter the relative rates of protein synthesis and degradation (Odedra et al. 1983; Tomas et al. 1979), which may raise the cost of net protein synthesis. There may also be an effect on physical activity (Beatty et al. 1971). Last, it is known that while corticosteroids reduce the size of skeletal muscle, visceral tissues are less affected and may even become enlarged (Hausberger \& Hausberger, 1958; Fain \& Czech, 1975). Metabolic variables, such as protein turnover and enzyme activity, are normal or increased in visceral tissues after corticosteroid treatment (Odedra et al. 1983; Woodward $\&$ Emery, 1987). Since there is evidence that visceral tissues have a higher metabolic rate than skeletal muscle (Koong et al. 1985; Webster, 1986), this effect would itself be expected to increase whole-body energy expenditure relative to body size.

Compared with males, female rats showed less weight loss, no obvious polyuria, and no reduction in either metabolizable energy intake or carcass energy gain after corticosterone treatment. It is likely that these differing responses were caused by the markedly higher turnover of corticosterone in female rats (Glenister \& Yates, 1961; Kitay, 1961), which would accelerate the clearance of exogenous hormone from the body. This sex difference is not consistently found in other species.

A number of reports indicate a species difference between rats and mice in the response to exogenous corticosteroids. Hyperphagia, increased fat deposition and reduced energy expenditure have been reported in mice (Babikian, 1962; Kekwick \& Pawan, 1965; Galpin et al. 1983). These effects are in some ways similar to those found in human beings (Walsh et al. 1984; Willcox et al. 1984; Horber et al. 1986).

Adrenalectomized rats are hypophagic, but grow normally when force-fed the same 
amount of food as control rats (Cohn et al. 1955). This suggests that adrenal steroids may affect appetite, but have no independent effect on energy expenditure. Endogenous corticosteroids are also thought to play a role in the genetically-obese $f a / f a$ rat and $o b / o b$ mouse, since many features of their obesity can be normalized by adrenalectomy (Fletcher, 1986; Warwick \& Romsos, 1988).

One aim of the present study was to determine how corticosterone-treated rats lose weight despite having relatively high metabolizable energy intakes. The results show first that the tissue lost consists mainly of protein and water and, therefore, has a low energy content. At the same time the treated rats maintained a relatively high energy expenditure. Perhaps the simplest explanation for these results is that corticosterone has no independent effects on energy balance. However, the substantial loss of lean body mass in the form of skeletal muscle may cause apparent changes when energy variables are expressed relative to body size. In addition, the presence of glycosuria will influence metabolizable energy intake.

This work was supported by a grant from the Cancer Research Campaign. The authors thank Professor G. R. Hervey, Department of Physiology, University of Leeds, for commenting on the manuscript.

\section{REFERENCES}

Babikian, L. (1962). Effect of hydrocortisone, corticosterone and cortisone on fat depots in mice on restricted diet. Physiological Zoology 35, 187-192.

Beatty, W., Scouten, C. W. \& Beatty, P. A. (1971). Differential effects of dexamethasone and body weight loss on two measures of activity. Physiology \& Behaviour 7, 869-871.

Bellamy, D. (1964). Effect of cortisol on growth and food intake in rats. Journal of Endocrinology 31, 8384

Cohn, C., Shrago, E. \& Joseph, D. (1955). Effect of food administration on weight gains and body composition of normal and adrenalectomized rats. American Journal of Physiology 180, 503-507.

Coyer, P., Cox, M., Rivers, J. P. W. \& Millward, D. J. (1985). The effect of catabolic doses of corticosterone on heat production in the growing rat. British Journal of Nutrition 53, 491-499.

Fain, J. N. \& Czech, M. P. (1975). Glucocorticoid effects on lipid mobilisation and adipose tissue metabolism. In Handbook of Physiology, vol. 6, pp. 169-178 [S. R. Geiger, editor]. Washington, DC: American Physiological Society.

Fletcher, J. M. (1986). Effects of adrenalectomy before weaning in the genetically obese zucker rat $(f a / f a)$. British Journal of Nutrition 56, 141-151.

Ford, L. E. (1984). Some consequences of body size. American Journal of Physiology 247, H495-H507.

Galpin, K. S., Henderson, R. G., James, W. P. T. \& Trayhurn, P. (1983). Effects of corticosterone acetate on energy balance in mice. Proceedings of the Nutrition Society 42, 159A.

Glenister, D. W. \& Yates, F. E. (1961). Sex difference in the rate of disappearance of corticosterone-4- ${ }^{14} \mathrm{C}$ from the plasma of intact rats. Endrocrinology 68, 747-758.

Hausberger, F. X. \& Hausberger, B. C. (1958). Effect of insulin and cortisone on weight gain, protein and fat content of rats. American Journal of Physiology 103, 455-460.

Horber, F. F., Zurchner, R. M., Herren, H., Crivelli, M. A., Robotti, G. \& Frey, F. J. (1986). Altered body fat distribution in patients with glucocorticoid treatment and in patients on long-term dialysis. American Joumal of Clinical Nutrition 43, 758-769.

Kekwick, A. \& Pawan, G. L. S. (1965). Metabolic effects of cortisone. Journal of Endocrinology 31, 265. 269

Kitay, J. I. (1961). Sex difference in adrenal cortical secretion in the rat. Endocrinology 68, 818-824.

Kochakian, C. D. \& Robertson, E. (1951). Adrenal steroids and body composition. Journal of Biological Chemistry 190, 495-503.

Koong, L. J., Ferrell, C. L. \& Nienaber, J. A. (1985). Assessments of interrelationships among levels of intake and production, organ size and fasting heat production in growing animals. Journal of Nutrition 115, 1383-1390.

Odedra, B. R., Bates, P. C. \& Millward, D. J. (1983). Time course of the effect of catabolic doses of corticosterone on protein turnover in rat skeletal muscle and liver. Biochemical Journal 214, 617-627.

Pullar, J. D. \& Webster, A. J. F. (1977). The energy cost of fat and protein deposition in the rat. British Journal of Nutrition 37, 355-363.

Rothwell, N. J. \& Stock, M. J. (1984). Sympathetic and adrenocortical influences on diet-induced thermogenesis and brown fat activity in the rat. Comparative Biochemistry and Physiology 79 A, 575-579.

Snedecor, G. W. \& Cochran, W. G. (1978). Statistical Methods, 6th ed., pp. 114 117. Iowa: Iowa State University Press. 
Tomas, F. M., Munro, H. N. \& Young, V. R. (1979). Effect of glucocorticoid administration on the rate of muscle protein breakdown in vivo in rats, as measured by urinary excretion of $N$-methylhistidine. Biochemical Journal 178, 139-146.

Van Es, A. J. H. (1986). Energy metabolism in man and animals. In Proceedings of the XIII International Congress of Nutrition, pp. 279-283 [T. G. Taylor and N. K. Jenkins, editors]. London: John Libbey.

Walsh, T. D., Chester, F. M., Daly, E. \& Jackson, G. P. (1984). Beneficial effect of corticosteroids on food intake amongst patients with advanced cancer. Proceedings of the Nutrition Society $43,44 \mathrm{~A}$

Warwick, B. P. \& Romsos, D. R. (1988). Energy balance in adrenalectomized $o b / o b$ mice: effects of dietary starch and glucose. American Journal of Physiology 255, R141-R148.

Webster, A. J. F. (1986). Efficiency of energy deposition in growth and fattening. In Proceedings of the XIII International Congress of Nutrition, pp. 288-292 [T. G. Taylor and N.K. Jenkins, editors]. London: John Libbey.

Willcox, J. C., Corr, J., Shaw, J., Richardson, M. \& Calman, K. C. (1984). Prednisolone as an appetite stimulant in patients with cancer. British Medical Journal 288, 27.

Woodward, C. J. H. \& Emery, P. W. (1986). Energy balance of corticosterone-treated rats in relation to body composition. Proceedings of the Nutrition Society 45, 52A.

Woodward, C. J. H. \& Emery, P. W. (1987). The activity of cytochrome $c$ oxidase (EC 1.9.3.1) in corticosteronetreated rats. Proceedings of the Nutrition Society 46, 95A.

Woodward, C. J. H. \& Emery, P. W. (1989). Energy balance in rats given chronic hormone treatment. 1. Effects of long-acting insulin. British Journal of Nutrition 61, 437-444. 